\title{
An Examination of Teachers Perceptions of Stakeholders Involvement in School Improvement Planning: The Case of Uganda
}

\author{
Cleophus Mugenyi \\ Mountains of the Moon University
}

\begin{abstract}
This paper reports on findings about the involvement of stakeholders in school improvement planning (SIP) in primary schools based on the perceptions and experiences of teachers; and proposes recommendations for improving their participation. The stakeholders include the head teachers, school management committee (SMC), teachers, inspectors of schools, pupils, and the community. A mixed methods approach involving survey and interviews was utilised to address research questions. The findings show that the levels of involvement of different actors vary according to school contexts and socio political climate. Whereas the pupils are never or rarely involved in improvement planning; the head teachers, SMC, teachers, inspectors of schools, and the community are always involved in varying degrees. The three major levels of involvement include sharing information, consultations and actual participation. Participation in SIP takes different forms including provision of labour, fundraising, attending school functions and meetings, visiting children at school, and contributing funds. The involvement of stakeholders in SIP is limited by illiteracy, community apathy, personal attitude, ignorance, political interference, and lack of training. The district education department and school management need to design strategies to improve involvement of stakeholders in SIP, and support supervision services.
\end{abstract}

\section{Introduction}

The late 1990s witnessed the government of Uganda embarking on systematic education sector planning which included designing development plans at ministry, district and school levels. The education strategic investment plan (ESIP) 1998 -2003 followed by the education sector strategic plan (ESSP) 2004 2015 designed with local and international support spells out the mission, priorities, resources, and targets for improving the quality of education in Uganda [18]. These two plans were designed against the backdrop of the introduction of universal primary education (UPE) in 1997 in Uganda. The introduction of UPE came with many challenges including inadequate teachers, infrastructure (especially classrooms and latrines), textbooks and other instructional materials, and limited community participation in school programmes [10]. One of the strategies adopted to improve the quality of primary education was school improvement planning (SIP) with the major objective of enhancing schools' capacity to manage challenges of UPE [14]. SIP is a continuous process by which stakeholders identify objectives, priorities and targets to be attained within a specified timescale, and use available resources to improve all aspects of schooling [14]. In this context, Bell [1] suggests that 'SIP has come to be the only legitimate approach for schools in preparing for their future' (p.33). However, Dunaway et al [5]) argues that 'little research has been done as to whether this 'accepted practice’ actually improves schools' (p.158).

This paper focuses on Masindi, the first district in Uganda, to adopt SIP through partnership with Link Community Development (LCD) an international non-governmental organization (NGO) and Ministry of Education and Sports (MOES). SIP was adopted as a strategy to improve teaching and learning, school management and governance, and community participation in education under the UPE programme [10].

The involvement of stakeholders in the process of SIP is a cornerstone for ownership of the school improvement plan and active participation in its 
implementation, monitoring and evaluation. Stakeholders represent different constituencies including foundation bodies, local community, central and local government, old students, teachers, local leaders and parents [8, 12]. However, few studies have explored the role of different stakeholders in improvement planning, yet they determine the success or failure of the school improvement plan. This study therefore investigated the teachers' perceptions regarding stakeholders' involvement in SIP. The stakeholders included head teachers, teachers, school management committee (SMC), school inspectors, pupils, and local community.

\section{Management of Primary Schools}

In Uganda, the 1997 Local Government Act introduced school-based management, and the Revised SMC Regulations 2000, empowers primary schools to manage their own development [10]. The SMC is the supreme governing body responsible for school operations and reports to the district education officer (DEO) and sub-county and district political leaders.

The SMC members participate in improvement planning by acting as a bridge between teachers and parents, promoting school community relations, and mobilising resources for school development [8]. According to Cuckle et al [2] the role of the governing body (SMC) is to regularly review the school operations and takes appropriate action, monitor the quality of education provision, discuss and approve the school improvement plan, and serve as mouthpiece of the parents and community. Therefore the SMCs play a major role in articulating different views that can lead to change and their demands and expectations exert pressure on head teachers and teachers to work hard to produce the desired results. The participation of SMCs in improvement planning varies from low, medium to high within schools [2]. Experience from England, shows that involvement of SMC in SIP is limited by lack of confidence and knowledge of the planning process, illiteracy, community apathy, personal attitude, communication barriers, and lack of training [11]. The SMCs cannot be involved in all aspects of SIP, but it is vital for them to understand the rationale and contents of the school improvement plan, and therefore contribute to implementation and outcomes.

\section{Participation of stakeholders}

Since the 1990 World Conference on Education for All in Jomtien Thailand, governments and development partners have focused efforts on improving access, equity, and quality of primary education especially in developing countries. The 2000 Dakar World Education Forum further committed countries to provide access to free and compulsory primary education of good quality by 2015 as one of the millennium development goals $[10,18]$. Primary education is one the basic human rights according to the Universal Declaration of Human Rights, Article 16 (1) which states 'everyone has the right to education. Education shall be free, at least in the elementary and fundamental stages. Elementary education shall be compulsory' [13].

In many countries it is the responsibility of the government and parents and/or local community to ensure that children of school going age are enrolled and complete the primary cycle to facilitate them acquire knowledge, life skills, and to proceed to secondary education and other levels.

The involvement of stakeholders in the planning process makes the school leaders accountable to the school community, local and central government. According to Davies [4] the stakeholders are involved in the process of SIP at three levels: sharing information, consultations and active participation (Table 1).

Table 1 Levels of stakeholders' involvement

\begin{tabular}{|l|l|}
\hline \multicolumn{1}{|c|}{ Level } & Means of participation \\
\hline Information & -School performance review \\
& (SPR) meetings \\
& -Regular SMC, PTA and general \\
meetings & -Sending pupils to inform \\
& $\begin{array}{l}\text { parents } \\
\text {-Radio announcements } \\
\\
\text {-Issuing circulars/letters }\end{array}$ \\
\hline Consultation & -Meetings \\
& -Telephone conversations \\
& -Radio programmes \\
\hline Participation & -Meetings \\
& -Construction works \\
& -Fundraising and charity walk \\
& -Visiting children at school \\
\hline
\end{tabular}

The introduction of UPE in 1997 in Uganda coincided with the enactment of the decentralisation policy that granted powers to districts to manage their own development. The districts are responsible for the recruitment and appointment of civil servants (e.g. teachers, head teachers, and education officers), undertaking projects and programmes for improving delivery of education services, developing educational plans and policies, and monitoring schools [8]. 
According to MoES [12] the implementation of UPE involves stakeholders at four levels:

(a) School (Head teacher, teachers, foundation bodies, village chairpersons, Parents Teachers Association (PTA), SMC, community, pupils, parents, and guardians);

(b) Sub- county (Sub-county Chief, Sub-county Chairperson, and Sub-county Councillors);

(c) District (District Chairperson, District Councillors, Resident District Commissioner, Chief Administrative Officer (CAO), DEO, Inspectors of Schools, Coordinating Centre Tutors (CCTs), NGOs, and mass media); and

(d) National (Ministry of Education and Sports, Ministry of Local Government, Ministry of Finance Planning and Economic Development, Members of Parliament, Education Funding Agencies, NonGovernmental Organisations, and mass media).

The level of involvement in the planning process among stakeholders varies depending on their roles in school management [7]. It is suggested that the higher the level of consultations and involvement of stakeholders, the better for the school as this enhances accountability, teamwork, and sharing of responsibilities.

\section{Role of Teachers}

Teachers participate in school improvement by developing strategies that promote effective learning, monitoring and assessing pupils, providing feedback on pupils learning, and managing classroom and school activities [6].

The SIP provides a framework for teachers to engage in management and leadership activities to enhance their knowledge, skills, and professional development [9]. Therefore, SIP is a tool that assists school staff and specifically teachers in their continuous school improvement efforts aimed at provision of quality education services. The delivery of the curriculum entirely depends on teachers' capacity and input; hence teachers are the single most important education resource in any country [17]. Teachers spend most time with the pupils, and hence can utilize their professional judgements, knowledge and skills to ensure effective learning through formal and informal monitoring and assessment [3]. Studies of school effectiveness have consistently shown that school improvement is determined by classroom effectiveness, which is the driving force of SIP. In this context, Fullan and Hargreaves [6] contend that 'proposals for change and improvement...come to nothing if teachers do not adopt them in their own classrooms and if they do not translate them into effective classroom practice' (p.22). Teachers' participation in SIP increases their willingness to contribute to the priorities, implement the set targets, establish networks within and outside the school, and monitor and evaluate teaching and learning.

International studies on educational change have consistently shown that the involvement of teachers in decision-making and responsibility-taking process is crucial for their receptiveness towards implementation of current and future educational change' [16] (p.13). Teachers can be involved in several ways including voluntarism, selection, request, and representation on school committees [15]. However, Stoll and Fink [15] warn that teachers cannot be involved in every aspect of the improvement plan. What is required of teachers is to be knowledgeable about the school vision, objectives and their roles in the improvement planning process. Teachers serve as change agents in the implementation of change at both classroom and school levels in partnership with the head teachers and other stakeholders.

\section{Research Approach}

The study adopted a mixed methods approach to gain broader and deeper understanding of the perceptions of teachers. The study was guided by three questions: (a) How are stakeholders involved in SIP? (b) In what ways are stakeholders involved in SIP? and (3) What factors limit effective participation of stakeholders? Data were gathered using a two stage approach involving a survey and interviews. Phase one of the study involved a questionnaire administered to 126 teachers; and 112 teachers returned the questionnaires that were analysed by the statistical package for social scientists (SPSS) computer software to produce descriptive statistics. This was done to provide a general understanding of the perceptions of teachers. The survey involved 62 out of 93 primary schools in the district that received improvement grants. The case study involved a purposive sample of nine schools selected based on: experience of improvement planning (infant, adolescent and mature); location (rural, semi-urban, urban); and enrolment (high, medium, low).

Phase two involved in-depth semistructured interviews with two teachers at each school who accepted to participate in the follow up interview after signing a consent form. Interviews were conducted with two teachers (T1 and T2) at each school. A total 
of 18 teachers (in 9 schools coded S1 to S9) were interviewed to understand the process and implications of SIP at school level. The interviews were tape recorded and transcribed. Data were analysed using thematic framework approach to identify key themes and patterns.

\section{Presentation of Findings}

The findings focus on results from the survey and interviews.

\subsection{Teacher's characteristics}

Regarding gender, $48 \%$ of the teachers were female and $52 \%$ were males. Over half of teachers (53.6\%) possess grade three teaching certificate. There were more male grade three teachers (55\%) than females (52\%) and Diploma male teachers (45\%) than female teachers $(41 \%)$. It is interesting to note that the only three graduates (5.6\%) and one untrained teacher (1.8\%) were female.

\subsection{Teachers' experience in service}

Teachers experience in teaching service ranged from 1 to $16+$ years. The majority of teachers $(40.2 \%)$ reported experience of 6 to 10 years. Less than onefifth of teachers (18.7\%) reported experience of 11 to 15 years. Slightly over one fifth (20.5\%) of teachers had experience of 1-5 years and 16+ years respectively. Schools have teachers with varying teaching experiences which is good for sharing knowledge and experiences of SIP.

\subsection{Teachers' experience of SIP}

Teachers' experience of SIP was categorised as very good, good, fair, and poor. Less than one-third of teachers (26.8\%) reported very good experience. Over half of teachers (62.5\%) reported good experience; and 9.8\% and $0.9 \%$ (one teacher) reported fair and poor experience respectively

\subsection{Stakeholders' involvement in SIP}

The activities in which stakeholders are involved in the SIP were measured on a five-point Likert scale (1 = never involved; $2=$ rarely involved; $3=$ not sure, 4=sometimes involved; $5=$ always involved). Analysis of stakeholders' involvement in improvement planning focused on five areas: SPR, selection of priorities, implementing action plans, evaluating improvement plans, and reporting outcomes.
6.4.1 Involvement in SPR. Almost all teachers reported themselves (93\%), head teachers (96.4\%) and SMC (87\%) as being always involved in SPR. More than half of teachers reported that the community (67.9\%) and inspectors of schools (59\%) were sometimes or always involved. Almost a third (28\%) of teachers were not sure of pupils involvement while close to half (44\%) reported that pupils were never or rarely involved.

6.4.2 Selection of priorities. Over three quarters of teachers reported themselves (83\%), headteachers (93\%), and SMC (78.6\%) as being always involved in selecting priorities. This may suggest that these stakeholders play a key role in selecting priorities in school improvement plans. More than half of the teachers (59\%) reported that pupils are either never or rarely involved. This may be an indication that pupils have less power in selecting priorities. Over half of teachers reported that inspectors of schools (57.1\%) and community (57\%) were sometimes or always involved; an indicator of active participation of the local community in school programmes.

6.4.3 Implementing the action plans. Almost all teachers (95\%) reported that head teachers were always involved in implementing action plans. Over three quarters of teachers (80\%) reported themselves as being always involved. This may suggest that head teachers coordinate with teachers to implement action plans at school and classroom levels. More than half of teachers reported that inspectors of schools (72.3\%) and community (58.3\%) were sometimes or always involved. Less than a third of teachers (30.4\%) reported that pupils were never or rarely involved. This implies that pupils work with other stakeholders to implement action plans. Over three quarters (88\%) of teachers reported that SMC were sometimes or always involved in implementing action plans. This implies that SMC are active participants in implementing agreed action plans focused at school improvement.

6.4.4 Evaluating improvement plans. Almost all teachers (93\%) reported themselves and head teachers (96.4\%) as being always involved in evaluating the improvement plans. Less than half of teachers (44\%) reported that pupils were never or rarely involved. Almost all teachers (96.4\%) reported that SMC was sometimes or always involved in evaluation. More than half of teachers reported that school inspectors (59\%) 
and community (67.9\%) were sometimes or always involved. The level of involvement in evaluating the plan appears to be related to school administrative structures. This may explain why the SMC, head teachers, teachers and SMC are always involved in evaluating the plan compared to the pupils.

6.4.5 Reporting Outcomes. Almost all teachers (92\%) reported that head teachers were always involved in reporting outcomes of improvement plans. Over half of teachers reported themselves (57\%) and SMC (62\%) as being always involved. Over half of teachers $(51.7 \%)$ reported that pupils were never or rarely involved. The pupils are never or rarely involved in reporting outcomes because they are not accountable to the head teacher or SMC. Over half of teachers reported that inspectors of schools (69.6\%) and community (51.8\%) were sometimes or always involved. The high level of involvement of head teachers in reporting outcomes may be related to the performance contract with the local government, which requires them to submit regular progress reports.

\subsection{Roles of Stakeholders}

Interviews were conducted with teachers to identify roles of key stakeholders. The case study schools were used as a unit of analysis rather teachers.

6.5.1 Teachers. At class level, teachers implement activities such as teaching, designing instructional materials and continuous assessment in partnership with parents and head teachers. All case study schools reported that the teachers' main responsibility is to implement priorities at class level: 'The activities in the improvement plan which I'm implementing in my class include assessing pupils performance, discipline of learners, production skills, rewarding pupils for satisfactory performance, guidance and counseling, monitoring and supervising pupils, sensitising the parents and pupils about the value of education, and promoting positive behaviour for mitigation and control of HIV/AIDS (T1, S7).

One of the roles of teachers is to manage discipline in class and within the school premises. The prefects, teachers on duty and deputy head teacher in charge of administration work with the head teacher to monitor discipline constantly during school time within and outside the class. In four case study schools discipline was reported as improving but in two rural schools indiscipline was reported as one of the causes of absenteeism and dropout. One teacher reported: $M y$ role is to implement the priorities including writing schemes of work and lesson plans, monitoring and supervising pupils, and ensuring that pupils observe school rules and regulations to be disciplined (T1, S2).

Teachers monitor and assess pupil learning according to set targets in the improvement plan. Continuous monitoring includes sharing information with the head teacher and staff in meetings about pupils' progress and syllabus coverage. In lower primary (grade 1 to 3), teachers conduct both formative and summative assessment following the thematic curriculum. In upper primary (grades four to seven), assessment is at the end of the every month and pupils also sit for end of term tests:

As a class teacher, I know better the needs of the class. I know which textbooks are needed. If certain areas are not being covered well, I gather data and forward it to the head teacher. If there are issues of absenteeism, I communicate with the head teacher and parents, and we discuss such matters in our meetings (T2, S7).

Teachers participate in reviewing the plan to assess progress and actions to be taken as needs arise. This is conducted through class meeting, staff meeting and consultations with stakeholders at regular intervals. One teacher reported: We review the plan every month. We meet as staff and review the plan; then brief the pupils about our progress in class and at assembly (T1, S1).

Teachers reported that head teachers supervise, monitor and evaluate teaching and learning. The head teachers use different strategies to monitor teaching including sitting in class and observing the lesson, standing outside the class and listening, checking pupils' exercise books, approving teachers' schemes of work and lesson plans, and debriefing the teacher at the end of the lesson. Teachers as implementers of planned activities participate in every aspect of improvement planning. The fact that teaching and learning is the main priority of improvement plans implies that what teachers do in the classroom contributes towards the outcomes.

6.5.2 Headteachers. The head teacher uses the improvement plan as a tool for school self-evaluation to review progress against set targets. The school 
performance review assists the head teachers to know the current situation in terms of progress, achievements, and challenges. The head teacher as a team leader regularly reviews the plan with the senior leadership team, and discusses the findings with teachers and SMC. The head teacher provides professional and moral support that keeps teachers focused on teaching to achieve the set targets. The professional support includes classroom supervision, in-service training, delegation of duties, appraisal for promotion, rewards and sanctions. Teachers' rewards include physical materials, words of encouragement, allowances, and recognition for outstanding performance. Teachers from school 2, 3, 6, 7 and 8 reported that they receive allowances, while teachers from schools 1, 4, 5 and 9 claimed that they receive physical materials. One teachers reported: 'The head teacher appreciates whatever we do at school. Sometimes, at the end of the term we receive rewards. It is a kind of incentive that your supervisor appreciates your work (T1, S5)'. Another teacher reported: 'All teachers receive 30 pounds per month from the school management besides government salaries. We are motivated to work hard and maintain the school standards' (T1, S6).

The roles of the head teachers include offering technical advice, implementing activities in the improvement plan and reporting outcomes to stakeholders. Head teachers adopt different approaches to manage the improvement plan, including guidance, counseling, rewards, consultations and networking with key stakeholders who hold them accountable.

6.5.3 School Management Committee. The role of SMC is to supervise and monitor school management in terms of attendance, discipline, development projects, and teaching and learning at school. Regular interaction between teachers and members of the SMC promotes cordial working relationships that enhance teamwork and cooperation. For example, members of the SMC in charge of discipline at school 2 trained parents on safety and health of children. One teacher reported that regular meetings were useful in addressing teachers' complaints: The SMC has a subcommittee that handles teachers' welfare. The chairperson of the SMC meets with teachers regularly to advise and guide them on what to do. The SMC visits the school, meets all the teachers and discusses with them the parents' concerns and listens to teachers' complaints. This has created harmony and cordial working relationship between the teachers and the school managers (T2, S2).
The chairperson of the SMC must approve the improvement plan before it is submitted to the district education office. Any improvement plan not endorsed by the chairperson is not accepted. This procedure is intended to promote participatory planning and transparency within the legal framework of decentralisation.

All nine schools, except school 3, reported that the chairpersons perform duties with little or no support from other members of SMC. The teachers perceived illiteracy and ignorance as a limiting factor to community participation in school activities. For example, schools 1,3 and 7 reported that most SMC members cannot read and interpret the contents of the improvement plan, hence they endorse whatever the staff and head teacher presents. Furthermore, these schools reported that SMC members never or rarely visit the school unless invited by the head teacher. This may be attributed to lack of time, limited commitment to the school, and inadequate knowledge about school management. One teacher reported: Some SMCs have outlived their usefulness. They have served for more than five years and are not active hence they appear to have lost interest in school programmes as they rarely come to school (T1, S4). Another teacher at school 3 reported: It is only the chairperson of the SMC who is vigilant and actually comes to monitor to see what is on the ground, because he is someone who is more enlightened compared to others (T2, S3).

The participation of the SMC in school programmes depends on its members' commitment to serve the public. The SMCs are more active in monitoring, compared to implementation.

6.5.4 Inspectors of Schools. The number of schools, compared to available inspectors makes it difficult to offer technical support to teachers, head teachers, and conduct routine monitoring. Inspectors of schools are therefore incapable of supervising and monitoring all schools and are forced to delegate some of their work to coordinating Centre tutors. A teacher reported: They are very few inspectors compared to the existing schools; hence some rural schools can spend a whole year without seeing an inspector. The district should recruit more inspectors so that schools are inspected effectively (T2 S 3).

Inspectors of schools provide technical advice throughout the improvement planning process to 
ensure that schools operate within the approved guidelines and regulations. They scrutinise the improvement plans before endorsing them for onward submission to the district education office. One teacher reported: The inspectors have helped schools to put in place strategies to address weak areas in the course of implementing the plan (T2 S5)

Inspectors of schools make choices about the schools to monitor based on the available resources and location. The involvement of other stakeholders, such as sub-county leaders, SMC, and political leaders in school inspection is limited. One teacher reported: The motorcycles inspectors use are old and are always complaining of lack of facilitation. Failure to inspect schools accounts for poor teaching and learning in our schools (T2 S1).

Monitoring schools and specifically the implementation of improvement plans by inspectors of schools, keeps school managers not only vigilant, but also focused on priorities and targets

6.5.5 Pupils. The involvement of pupils in improvement planning promotes cooperation and aids implementation of school activities. Six case study schools reported that pupils were involved in several activities of SIP including attending SPR meetings, participating in fundraising, and maintaining discipline. Pupils' participation begins with the SPR meeting, which is attended by the head girl, head boy and prefects, to present the pupils' views to the stakeholders.

The involvement of pupils' leaders in identifying challenges and priorities enhances schools' efforts to implement the improvement plan. Six case study schools reported that pupils were involved in all stages of improvement planning, while three schools reported that pupils were mostly involved in implementation. However, the degree of pupils' participation varies according to the micro politics and school priorities. One teacher reported: 'Pupils are not involved in designing the plan, but are involved in carrying out some of the set targets in the improvement plan (T1, S9)'. Another teacher at School 6 reported: Pupils have to know that they have a role to play and the improvement plan is for their own good (T1 S6).

The pupils also participate in mobilising resources in several ways. Pupils contribute food and other materials for sale during fundraising, and participate in charity walks. A teacher at School 4 reported: They sing for parents and guests and bring items for sale because they know the money will be used to improve the school (T2 S4). All case study schools reported that pupils were involved in monitoring school activities such as teaching and learning and cleanliness of compound, classrooms and latrines. The class monitors and prefects monitor school activities with the support of class teachers and the head teacher.

Sharing of responsibilities amongst stakeholders, including pupils, is part of distributed leadership that promotes effective school management. Pupils' involvement in improvement planning is part of participatory planning, which helps them to understand school priorities, achievements and challenges.

6.5.6 Community. The community plays a key role in the existence and sustainability of a school. It is involved in planning for the school and implementing agreed action plans. One teacher reported: 'Parents come to school see how their children are performing and this helps teachers in planning and carrying out what was agreed on in the parents meetings (T1 S5). In rural areas, schools reported that the community participate in collecting local materials. It is easier to collect materials than contribute money due to poverty and ignorance. A teacher in a rural school reported: 'the local community contributed materials for construction of a two classroom block... contributed sand, stones, bricks, money, or physical labour (T1 S7)'.

The community act as key witness to all important functions and ceremonies that take place at schools. One teacher reported: 'The community is always invited to attend meetings and school functions such as speech days, school open days, music festivals, games and sports competitions to witness and evaluate school performance (T1 S3)'.

However community involvement is also limited by certain factors including poverty, illiteracy, ignorance and political interference. One teacher reported: Some members of the community are illiterate and do not know the value of education, hence withdraw children from school. In addition, politicians interfere in school management and discourage the local community from participating in some programme for example contributing money towards construction of classrooms and paying for children to have lunch at school (T1 S1). Inadequate participation of community members limits the extent to which schools can achieve the set targets in improvement plans. One teacher reported: Some of the parents and community 
members do not understand what the school development is all about. However much you explain some do not understand (T1, S8).

\section{Discussion}

The study focused on key stakeholders involved in the process of improvement planning namely head teachers, teachers, SMCs, community, inspectors of schools, and pupils. These stakeholders take on a range of roles and responsibilities in process of SIP. This study categorised these stakeholders into three different groups (actors) with diverse roles and responsibilities (Table 2).

Table 2. Actors in the SIP process

\begin{tabular}{|l|l|l|}
\hline Categories & \multicolumn{1}{|c|}{ Actors } & \multicolumn{1}{|c|}{ Roles } \\
\hline Professionals & Inspectors & Enforcers/regulators \\
\cline { 2 - 3 } & $\begin{array}{l}\text { Head } \\
\text { teachers }\end{array}$ & $\begin{array}{l}\text { Implementers / } \\
\text { professional learning } \\
\text { community leaders }\end{array}$ \\
\cline { 2 - 3 } & Teachers & Implementers \\
\hline Volunteers & SMCs & $\begin{array}{l}\text { Custodian of public } \\
\text { values / moral } \\
\text { guidance }\end{array}$ \\
\hline Consumers & $\begin{array}{l}\text { Pupils, } \\
\text { community }\end{array}$ & $\begin{array}{l}\text { Recipients of } \\
\text { education }\end{array}$ \\
\hline
\end{tabular}

The categories seem to explain the varying levels of stakeholders' involvement in different stages and the roles they play in SIP. Literature review shows that involvement of stakeholders in SIP creates a sense of ownership, commitment and continuity of school improvement [9].

The levels of involvement of different actors vary according to their roles and responsibilities. The participation of the SMC in school programmes depends on its members' commitment to serve the public. Schools have both active and passive members which determine the extent to which members are involved in SIP. The SMCs are more active in implementation and monitoring, compared to reporting outcomes due to limited technical knowledge about school management, teaching and learning.
The pupils are never or rarely involved in key stages of improvement planning because they are more of recipients of planned activities than implementers. Sharing of responsibilities amongst stakeholders, including pupils, is part of distributed leadership that promotes effective teaching, learning and school management. Pupils' involvement in improvement planning is part of participatory planning, which helps them to understand school priorities, achievements and challenges.

The findings show that the good working relationship between the head teacher and other stakeholders within and outside school are crucial in management of the process of school improvement. However, some schools with poor working relationships with teachers, governing body, inspectors of schools and politicians experience difficulties in managing the implementing improvement plans. This study confirmed previous findings that collegiality and friendly working relationships with stakeholders are significant factors in the process of school improvement [9, 10, and 11].

The head teachers, teachers, inspectors of schools, community and SMCs are always involved. The community (as consumers) are least involved in evaluating and reporting outcomes of the improvement plans. This suggests that implementers and enforcers are accountable to local and central government, and the community. The findings are consistent with previous research in the United Kingdom by Giles [7] which found pupils were least involved, while head teachers, and teachers were always involved. The participation of SMC varied from low, medium, to high across case study schools as indicted in previous research by Cuckle et al [2]. Similar reasons to those found in England accounted for limited involvement of SMC in Masindi, such as lack of confidence and knowledge of the planning process, community apathy, personal attitude, communication barriers, and lack of training [11].

The limited number of inspectors of schools affects support supervision and monitoring of schools to improve the quality of teaching, learning and school management. This implies that inspectors of schools provide limited guidance and support in the process of SIP, hence failing to regulate some of the school programmes. As earlier research by IOB [10] has shown inadequate inspectorate staff and funds limits school supervision and support services and consequently most rural schools are rarely inspected. 
However, where school inspection is conducted, it acts as a catalyst for school improvement.

The volunteers are accountable to the community and politicians at sub-county and district level, while professionals are accountable to professional leaders at district levels (CAO and DEO). It appears the consumers are accountable to professionals and volunteers to a limited extent. The cyclic process of accountability and symbiotic relationship amongst actors is crucial for head teachers to manage the improvement planning process. Given the fact that consumers are at the receiving end, they only complain to other actors of the quality of the education services. Lack of social capital within the community limits the extent to which they can benefit from the elected representatives (councillors and members of parliament) and make independent decisions focused on school improvement. Community participation is therefore limited by political interference, ignorance, and illiteracy, which continue to widen the gap between urban and rural schools [10].

The challenge of the head teachers as leaders of a professional learning community is to ensure harmony and manage conflicts that may derail sustainability of SIP. The head teacher's role is to provide technical advice to volunteers, consumers, professionals (teachers), and liaise with external professionals (CCTs, and inspectors of schools) and political leaders at various levels [8]. More importantly, head teachers work with the professionals to meet the teachers training needs; and volunteer to support teachers in classroom management and teaching. The fact that teaching and learning is the main priority of improvement plans implies that what teachers do in the classroom contributes towards the outcomes. The external professionals (e.g. inspectors of schools) collaborate with head teachers and other actors to enforce and regulate education policies and guidelines related to SIP [5]. The school context and social political climate in which teachers operate determine to some extent the degree to which they can be held accountable for school improvement. The consumers expect the head teacher to provide strong leadership that leads to creating and sustaining effective schools.

\section{Conclusion}

The head teacher needs the skills and knowledge to be able to interact and communicate with stakeholders to achieve the objectives of the improvement plan. At school level, the external and internal stakeholders interface with different agendas. The role of the head teacher as a professional leader and change agent is to develop trust and network with all stakeholders to hold them together. Regular interactions with stakeholders through meetings and consultations build trust, confidence and enhance school community linkages and efforts towards school improvement. Therefore, the ability of the head teacher to focus on a right area(s) may provide the opportunity to produce the expected results. This requires the head teacher to develop transformational leadership. The literature base highlights transformational leadership as a conduit to school improvement by which the head teacher uses his/ her intellectual capital to transform actors into a team of collaborators and utilise the school context and socio-political climate to manage the process of improvement planning to achieve the expected outcomes. While inspectors of schools play a key role in monitoring the quality of education and school standards, their efforts are not supplemented by other stakeholders especially the local politicians and technical staff at sub-county level. The participation of others stakeholders not only in monitoring the improvement plans but also the teaching and learning process and management of the school will greatly contribute to school improvement. The district education department needs to support head teachers by sensitizing the community on their roles and responsibilities and the value of education in local and national development. The district education department needs to work with head teachers to design friendly monitoring tools that schools can use regularly to monitor progress in all aspects of schooling including the improvement plans with or without the presence of inspectors of schools.

The three groups of stakeholders namely consumers, professionals and volunteers are involved in improvement planning in varying degrees. The findings show that stakeholders' involvement in improvement planning is dependent on their roles and responsibilities in school leadership and management. However, the attitudes and the extent to which each stakeholder plays his/her roles and responsibilities determines to the degree of their involvement in SIP. The implementation, sustainability and outcomes of improvement plans vary according to the school contexts and socio political climate; and hence stakeholders have different experiences and understanding of the SIP process 


\section{References}

[1] Bell, L. Strategic planning in primary schools: A tale of no significance. Management in Education, 2004, 18 (4), pp. $33-36$.

[2] Cuckle, P., Dunford, J., Hodgson, J. \& Broadhead, P. Governor Involvement in improvement planning: from tea parties to working parties. School Leadership and Management, 1998, 18 (1), 19 - 33.

[3] Davies, P. (2002) What is School improvement and how does it work in Practice? Briefing Papers No. 5 [online]. Available at: www.educationforum.org.nz [Retrieved on 5 May 2012].

[4] Davies, B. (2006) Process not plans are key to strategic planning, Management in Education, 20 (2), 11 - 15

[5] Dunaway, D.M., Kim, D., \& Szad, R. (2012).Teacher and principal perceptions of the purpose and value of the school improvement plan process. The Educational Forum 76(2), 158-173.

[6] Fullan, M. \& Hargreaves, A. What's worth fighting for in your school: Working together for improvement. Open University Press in association with the Ontario Public School Teachers, Buckingham, 1992.

[7] Giles, C. (1995) School based planning: Are UK schools grasping the strategic initiative? International Journal of Educational Management, 9 (4): 4 - 7

[8] Government of Uganda Local Government Act. Government of Uganda, Kampala, 1997.

[9] Hargreaves, D. H. \& Hopkins, D. The Empowered School: The Management and Practice of Improvement planning, Cassell, London, 1991.

[10] IOB Primary Education in Uganda: IOB Impact Evaluation, No. 311, The Hague: IOB, 2008.

[11] MacGilchrist, B. \& Mortimore, P. The Impact of school development plans in primary schools. School Effectiveness and School Improvement: An International Journal of Research, Policy and Practice, 1997, 8 (2): 198 - 218.

[12] MOES Guidelines on: Policy, Planning, Roles and Responsibilities of Stakeholders in the Implementation of Universal Primary Education (UPE) for Districts and Urban Councils. Ministry of Education and Sports, Kampala, 2008.

[14] Morsink, J. The Universal Declaration of Human Rights: Origins, Drafting and Intent. Philadelphia: The University of Pennsylvania Press, 1999.

[15] Mugenyi, C. \& Chapman, C. Universal primary schooling and planning for improvement: The perspectives and experiences of stakeholders in Uganda, Literacy
Information and Computer Education Journal (LICEJ), 2010, 1, (1).

[16] Stoll, L. \& Fink, D. Changing Our Schools. Open University Press, Buckingham, 1996.

[17] Swanepoel, C. \& Booyse, J. The involvement of teachers in school change: A comparison between the views of school principals in South Africa and nine other countries. South African Journal of Education, 2006, 26 (2), 189-198.

[18] UNESCO, EFA Global Monitoring Report: Reaching the Marginalised. Paris: UNESCO, 2010

[19] Ward, N., Penny, A. \& Read, A. Education Reform in Uganda 1997-2004: Reflections on Policy, Partnership, Strategy and Implementation, DFID, London, 2006. 